Revista Iberoamericana, Vol. LXXV, Núm. 229, Octubre-Diciembre 2009, 1003-1036

\title{
POETAS PUERTORRIQUEÑOS EN CHICAGO ${ }^{1}$
}

POR

\author{
MARC ZimMERMAN \\ University of Houston
}

\begin{abstract}
¿Dónde están los poetas latinos? Quizás en la taberna del barrio ahogando sus pensamientos en cerveza americana o vino, como el resto de los latinos. Pensando en su país, donde la tierra es tibia. Sí, pensando en mi viejita. El vino es bueno cuando la mente desata pensamientos tales como ¿por qué? Dormir en la nieve cuando nuestro país es tan calientito, ¿dónde están los poetas latinos? Yo no sé, quizás durmiendo en la nieve o de vacaciones en la cárcel del condado Cook.
\end{abstract}

\section{INTRODUCCIÓN}

En un artículo publicado hace varios años (Zimmerman, "Transplanting” 77) cité el poema precedente compuesto a finales de la década del setenta por el entonces

\author{
Where are the Latin poets? \\ Maybe at the neighborhood tavern, \\ like the \\ rest of the Latins drowning their thoughts \\ on American beer or wine. \\ Thinking about back home \\ where the land is warm. \\ Yes, thinking about mi viejita \\ Wine is fine when the mind unwinds \\ thoughts such as, why? \\ Sleeping in the snow when \\ our country \\ is so warm, \\ where are the Latin poets? \\ I don't know, maybe sleeping in the snow \\ or vacationing down at Cook County Jail.
}

\footnotetext{
La investigación para el primer borrador de este ensayo (ver Zimmerman 1990) fue patrocinada por la Oficina de Investigación de Ciencias Sociales de la Universidad de Illinois en Chicago, y una pequeña beca de investigación en el periódico Vida Latina proporcionada por el proyecto Recovering the Hispanic Heritage. Quiero reconocer la invalorable participación de Carlos Cumpián de MARCH, INC., Movimiento Artístico Chicano; también de Mónica Winter, Delia Tapia, Dalia Sabaliaushas, José Resto, Vírgin López, Mario Gamboa y Andrea Barrientos, estudiantes en el Programa de Estudios Latinoamericanos (ahora LALS) de la Universidad de Illinois en Chicago. A menos que se indique lo contrario, las citas sobre los detalles biográficos relacionados a David Hernández y Salima Rivera fueron tomadas de sus respuestas a un cuestionario que escribí en febrero de 1988. Los comentarios de Nicolás Kanellos sobre la penúltima versión están señalados con las iniciales "NK".
} 
joven chicago-riqueñoAlfredo Matías provocativamente titulado “¿Dónde están los poetas latinos?" Hoy, después de muchos años de desarrollo literario latino, quizás sea innecesario repetir la pregunta de Matías. La literatura Latina ha cobrado una presencia tan significativa que ha obligado a algunos críticos a redefinir el canon literario de los EE.UU. Del mismo modo los científicos sociales intentan precisar la importancia de los latinos tanto para los EE.UU. como para las Américas en general.

De hecho, el panorama empieza a cambiar aunque no de manera espectacular, ciñéndose a los alcances de Chicago implícitos en la pregunta de Matías. No hay muchos escritores chicago-latinos reconocidos y de presencia nacional, pero al menos hay cinco voces considerables en la constelación nacional: Carlos Morton, dramaturgo; Laurence Gonzales, establecido escritor de prosa de Evanston; y por supuesto, las bien conocidas Ana Castillo, Sandra Cisneros y Achy Obejas. Estos escritores son de origen chicano y cubano; hay muchos otros escritores latinoamericanos y latinos en Chicago. Sin embargo, una pregunta sale en todo eso: “¿Dónde están los poetas puertorriqueños?” Y ¿cuál es su contribución a la escena chicago-latina, a la escena puertorriqueña y a la Latina de los EE.UU.?

Para enfocar este problema desde un ángulo distinto: hace algunos años, en su introducción a una antología de poesía puertorriqueña en los EE.UU., Efraín Barradas señaló enfáticamente la falta de continuidad y comunidad entre los escritores nuyo-ricanos y los de la isla (11). Los escritores chicago-riqueños fueron eliminados de ambos sectores y sólo uno de ellos aparece en la antología citada. Entonces, ¿dónde han estado estos escritores Boricuas de Chicago y qué significación ha tenido su obra?

Lo que sigue es una mirada a la emergencia de la poesía chicago-riqueña y su función en el desarrollo del mundo latino. Propongo que es imposible entender la escritura chicago-riqueña aislada de un contexto mayor. $Y$ de hecho, esta necesidad de una perspectiva Latina más amplia vale para el contexto social chicago-riqueño y latino del medio-oeste en general -como sostuvo convincentemente Félix Padilla (Latino). Por otro lado, una perspectiva chicago-riqueña es también necesaria para la comprensión de la realidad nacional puertorriqueña y Latina en general.

Con respecto a la escena de Chicago, podría ser que la habilidad de Carlos Morton de romper con sus orígenes geográficos específicos estuviera relacionada

\footnotetext{
2 Significativamente, en relación al tema de este estudio, el poema de Matías no aparece en una publicación puertorriqueña específicamente, sino en dos medios de concepción muy diferente: primero, en el número especial de la Revista Chicano-Riqueña, Nosotros (1977): 37; y luego en la publicación de corta vida con base en Chicago del Movimiento Artístico Chicano (MARCH), Abrazo, 2 (1979): 10.
} 
a sus esfuerzos por pasar por "puertorriqueño" (Morton 4). ${ }^{3}$ Las construcciones de la liberación de la mujer Latina en Ana Castillo (1988) y Sandra Cisneros (1988) también se benefician de modelos alternativos a menudo puertorriqueños. Los escritores chicago-riqueños casi siempre se refieren a sus raíces específicas aunque también las relacionan con su propia experiencia de opresión, tanto a orientaciones afro-americanas como mexicanas o chicanas.

Desde sus primeros escritos, los poetas chicago-riqueños hablaban de lo latino, de la identidad latina o, con mayor frecuencia, de la poesía latina. Quizás por su reducido número, por ser una ínfima subcultura de escritores y artistas, o a lo mejor debido al carácter frágil e impreciso de su sentido de nación, más que sus homólogos mexicanos, tendieron a moverse más allá de su filiación nacional con lo latino y con tendencias tercermundistas y minoritarias al tiempo que afirmaban sus propios parámetros de identidad. No en vano la mayor contribución del área de Chicago a la bulliciosa escena Latina nacional viene de la Revista ChicanoRiqueña del estadounidense-puertorriqueño Nicolás Kanellos. De esta manera el tema del latino como opuesto a la identidad estrictamente puertorriqueña es uno de los grandes aportes de los escritores chicago-riqueños a la escena literaria Latina en general.

Este ensayo presentará una visión de conjunto de la escritura chicago-riqueña a fin de establecer un marco para nuestro objetivo central: una mirada a la primera promoción consolidada de poesía chicago-riqueña representada por David Hernández, Salima Rivera y otros poetas de Chicago que aparecen en el número especial, Nosotros de la Revista Chicano-Riqueña (1977).

\section{ESCRITORES CHICAGO-RIQUEÑOS: UNA VISIÓN GENERAL}

Existen textos puertorriqueños escritos en Chicago con anterioridad a las grandes corrientes de asentamiento de los años cuarenta y cincuenta a raíz de la llegada de los primeros puertorriqueños al área. Conversaciones con veteranos de la comunidad indican la existencia de décimas y plenas, poemas de nostalgia y exilio, etc., escritos en Chicago con anterioridad a la década de 1970 aunque nunca he sido capaz de identificar uno que haya sido claramente originado en Chicago ${ }^{4}$

\footnotetext{
3 Hijo de padres cubanos y mexicanos, Morton escribe que un amigo "intentaba ser un hermano del alma y yo un puertorriqueño"; también que su "barrio era un multicolorido arcoiris de nacionalidades", que incluía sensuales comedores de arroz de la que alguna vez fue una isla prístina" (4-5). Morton fue amigo de David Hernández a comienzos de los años setenta. Más tarde escribiría sobre teatro puertorriqueño en Nueva York, aunque su trabajo más importante sería como dramaturgo chicano en el sudeste de los EE.UU.

4 Bajo mi supervisión, la investigación preliminar llevada a cabo por el poeta chicano Carlos Cumpián mediante el proyecto Recovering the Hispanic Heritage no reveló definitivamente ninguna escritura
} 
en publicaciones anteriores, como El Puertorriqueño o Vida Latina. La escritura chicago-riqueña y su desarrollo literario general han sido relativamente limitados, pero actualmente hay unos cuantos representantes dignos de mencionarse.

Durante mucho tiempo parte de la escena de Chicago, primero como co-deejay de un programa de gran popularidad llamado Mambo Express de la emisora local del sistema PBS, junto a Víctor Parra, líder de la banda chicana de mambo, y después como miembro de personal del Latino Institute de Chicago, Billy Zayas sobresalió en la comunidad puertorriqueña de los setenta y ochenta. Capaz empresario cultural (emcee)-trabajó como escritor de anuncios comerciales, jefe de campaña política para el candidato a alcalde Larry Bloom, entre otros, comentador del desfile chicago-riqueño para la televisión, etc.-, Billy Zayas fue también coescritor de una obra de teatro titulada Carnicería Rodríguez, que gira en torno a la política Chicago-Latina anterior a Harold Washington (el alcalde negro de la ciudad a fines de los 80). Anticipando algunos de los temas claves relacionados con lo latino que saldrían a la luz en la campaña de Washington, Carnicería es por momentos un esfuerzo brillante escrito en colaboración con otros dos talentosos escritores cubanos locales, Achy Obejas y Jorge Caruso, probablemente una de las pocas obras teatrales Latinas de ciencia ficción -aunque sólo sea porque trata de un puertorriqueño (estupendamente representado por Zayas) que posee su propio mercado y que emplea a un cubano e incluso a un argentino. En el curso de la obra, los latinos aprenden a unirse para luchar contra aquellos que los usan y explotan. En este y otros aspectos la obra anticipa no sólo la era de Washington, sino el llamado que hace Jesse Jackson para crear una "coalición multicolor" (Rainbow Coalition). ${ }^{5}$ Zayas también escribió un corpus de poesía todavía inédita, desarrolló y puso en escena innumerables rutinas cómicas y publicó una serie de bosquejos humorísticos puertorriqueños en un periódico local latino, The Lawndale News, para terminar desapareciendo de la escena pública en los últimos años.

Volviendo a la poesía, en los ochenta surgió otro escritor, Ralph Cintrón, un nativo de Mayagüez que creció en el mundo chicano de Mercedes, Texas -el pueblo del novelista Rolando Hinojosa-antes de partir al norte para desarrollarse como un poeta promisorio con fuertes inclinaciones metafísicas. Para mantener y profundizar lo que quedaba de sus raíces puertorriqueñas, como editor de la efímera revista Latina Ecos y esporádico escritor de poemas con claras características étnicas, Cintrón produjo una obra inédita que reflexiona sobre lo sucedido en su isla desde la época de Muñoz Marín. Posteriormente escribiría un libro Angel's Town (1997), un estudio

Chicago-riqueña anterior a 1970 -en parte porque no pudimos verificar si los pocos fragmentos encontrados fueron realmente escritos y no simplemente publicados en Chicago.

5 Para el Acto I de Carnicería Rodríguez, ver Caruso, Obejas and Zayas, -con una nota introductoria (Zimmerman, “A Meaty”). 
sobre la lucha de los latinos - especialmente mexicanos-por ganarse "el respeto en un mundo que les niega respeto" en Aurora, Illinois, un suburbio de Chicago. Se trata de una obra etnográfica más acertada y dramáticamente concebida que casi todos los poemas y memorias que conocemos en la literatura chicago-riqueña.

Otros pocos autores redondean el período en que finalmente las escritoras estadounidense-puertorriqueñas salen a la palestra. Aurora Levins Morales y Rosario Morales incorporan alguno recuerdos de Chicago en su Getting Home Alive (1986). El mismo año Clementina Souchet autopublicó Clementina: Una historia sin fin (México, 1986), autobiografía que describía en detalle su odisea desde Peñuelas, Puerto Rico, hasta sus años en Chicago, primero como esposa y luego como divorciada que después hizo carrera como periodista y trabajadora comunitaria puertorriqueña y que, eventualmente, fuera nominada diputada de la "Comunidad Hispana" por el gobernador republicano Jim Thompson, hace ya algunos años. Según la autora, su esposo era un ingenuo engatusado por el siniestro movimiento de independencia de Chicago de los años cincuenta. En las páginas más fascinantes del libro vemos cómo este se va involucrando con los independentistas locales en reuniones conspiratorias de actividades planeadas para asaltar el Congreso. Horrorizada por los amigos de su esposo y por el peligro que estos representaban para él y sobre todo para su pequeño hijo, Souchet describe con orgullo cómo logró salvar a su esposo y quizás también a Harry Truman al denunciar al grupo al FBI, sirviendo como espía para esa organización y ciertamente ayudando, afirma, a frustrar la conspiración y poner tras las rejas a muchas de esas almas erradas y trastornadas, incluida la de su esposo, que en la tierra de la oportunidad le estaban dando un mal nombre a la patria y al pueblo que los vio nacer.

Este libro, floridamente escrito, complaciente y falto de autocrítica es, incluso en estos sentidos, un valioso documento que ofrece una perspectiva del mundo chicago-riqueño de los 50 y 60 , mundo de independentistas y conformistas sociales, de revolucionarios y oportunistas. Sobre todo, revela al chicago-riqueño en la era de la maquinaria política de Daley. Clementina es una mujer formada por su clase y su tiempo, que vive todas las pretensiones inscritas en su nombre, codeándose con dignatarios anglos, políticos de organización, empresarios latinos y celebridades mexicanas y Latinas que llegaron a la ciudad y que a su vez la recibieron en sus casas. Colmada de copias de cartas, documentos, fotos, etc., esta narrativa testimonial hace de su protagonista una versión femenina puertorriqueña del Lazarillo de Tormes, una pretenciosa Moll Flanders a lo boricua.

Dos años después de la aparición del libro de Souchet, otro prosista, Leonardo Rodríguez, obtuvo el apoyo del Puerto Rican Parade Committee y otras fuentes, para publicar un escueto libro de viñetas titulado They Have to be Puerto Ricans (1988), que habla de los chicago-riqueños que viven de la asistencia social pero exhiben un 
nacionalismo de consigna crudo y superficial, malogrados por su dependencia de los EE.UU., con el más bajo sentido de autoestima pero aún así, luchando -al menos algunos de ellos- por mantener algún tipo de identidad e integridad cultural.

En los noventa y en lo que va del presente siglo, por lo menos otros seis chicagoriqueños produjeron una obra digna de ser mencionada. Adolfo Colón publicó Cantos de Seboruco, un libro de poemas de corte más bien tradicional centrados en la isla que incluye décimas y otras formas tradicionales en una obra que revela a un poeta talentoso y comprometido, cuya representación romántica de la vida del jíbaro parecería haber sido nutrida de sus muchos años de residencia urbana. Colón también escribió cuentos breves en los que se incluyen los relatos "Una obra maestra" y "La gran ciudad," publicados en Voces en el viento (1999: 20-24, 101-104) del fallecido John Barry. Lourdes Lugo publicó el volumen, Poemas que me desnudan y me definen (1992), donde expresa sus simpatías independentistas y feministas y en los que incluye algunas fotos provocativas que muestran aspectos de su trayectoria política y personal. Por otra parte, cinco puertorriqueños de avanzada -Eduardo Arocho, Sonia Báez Hernández, Johanny Vásquez, Juana Goergen y Frank Varela- han infundido nueva vida a la poesía chicago-riqueña, aunque se alejan claramente del modelo de poesía callejera desarrollado por los poetas Nuyoricanos y el grupo inicial de David Hernández en Chicago. Goergen ha aparecido recientemente en una antología de escritores latinos de Chicago y otra de escritoras Latinas del Medio Oeste: la primera, editada por la poeta chicago-mexicana Olivia Maciel (1998) y la segunda, por Johanny Vásquez y la chicana Brenda Cárdenas (2001). En el mismo volumen Báez Hernández publicó "Container" y "There Is Something"; mientras que "Born Equal" aparecía en el número del Centrode Estudios Puertorriqueños dedicado a Chicago. Pero Hernández apenas estaba comenzando a publicar en Chicago cuando su lucha contra el cáncer y circunstancias familiares la obligaron a emprender una nueva fase de su vida en Miami. Arocho, comprometido activista comunitario, publicó dos poemas en el mismo número del Centro de Estudios Puertorriqueños dedicado a Chicago. Recientemente aparecieron sus tres primeros poemarios: Poems behind the Mascara (2002), Paseo Boricua Renaissance (2003) y The Fourth Tassel (2005), con trabajos que celebran aspectos de la vida puertorriqueña tanto en Chicago como en la Isla, y sobre todo en el volumen más reciente, otros acerca de discriminación racial.

Frank Varela, un poeta educado en la Universidad Católica de Ponce, pero con una larga residencia en los EE.UU., primero en el área de Nueva York, luego varios años en Chicago y actualmente en Cleveland, trabajó durante su permanencia en Chicago como recaudador de fondos y bibliotecario, y fue miembro de la directiva del Movimiento Artístico Chicano, que publicó su obra poética. Su primer volumen, Serpent Underfoot -con introducción y algunas traducciones del académico 
chicago-riqueño Luis Felipe Díaz- retrata etapas personales importantes, y de la vida puertorriqueña en el área del Parque Humboldt de Chicago. Su segundo libro, Bitter Coffe (2001), continúa algunas de las líneas desarrolladas en Serpent Underfoot, pero también presenta las reflexiones del autor sobre figuras claves de la historia, cultura y literatura de Puerto Rico y los EE.UU. como William Carlos Williams, Arturo Alfonso Schomburg, Pablo Casals, José Campeche, Julia de Burgos, Pedro Albizu Campos y Ramón Emeterio Betances, incluso Ezra Pound quienes, aparecen en una colección que apunta en diferentes direcciones pero principalmente se enfoca en la reconstrucción de la memoria de Puerto Rico.

Claramente más política que la obra de la mayoría de los escritores que hemos visto es la poesía sobre los prisioneros de guerra pertenecientes a las FALN (Fuerzas Armadas de Liberación Nacional) de Carmen Valentín, Alejandra Torres y Luis Rosa. Por lo general publicadas en periódicos y boletines de las FALN y del MLN (Movimiento de Liberación Nacional), la mayor parte de esta poesía encuentra su significado como otro modo de expresión militante, para comunicar las urgencias del grupo y quizás como terapia para los prisioneros y simpatizantes más íntimos. Pero a veces estos escritores van más allá del lenguaje convencional o los clichés del consuelo para dar testimonio de sus ideales revolucionarios o su situación como prisioneros y creyentes apasionados. Productos genuinos de las experiencias urbanas de Nueva York y Chicago que marginaron, anglizaron y cosificaron a muchos, a la vez que condujeron a otros a diversas formas de resistencia política y cultural, los poetas de las FALN, prisioneros de guerra o partidarios, representan una dimensión de la poesía y la realidad chicago-riqueña que requiere un estudio más extenso a fin de comprender la totalidad de la expresión poética boricua de la diáspora.

Otro fenómeno que se da en Chicago es el surgimiento de narrativas en primera persona que pueden ser clasificadas como testimonio y que de algún modo tienen un valor etnográfico similar a la narrativa del "crack" de Philippe Bourgois en la Nueva York de los noventa. Después de publicar el primer libro dedicado enteramente a los puertorriqueños en Chicago (1987), Félix Padilla presentó The Gang as an American Enterprise (1992), lleno de narrativas en primera persona que analiza la vida de las pandillas chicago-riqueñas como un ejercicio empresarial. Luego, en base al testimonio que recibió de Lourdes Santiago, presenta la vida de una mujer chicago-riqueña en los márgenes del mundo de las pandillas: Outside the Wall: A Puerto Rican Woman's Struggle (1993).

Últimamente, Reymundo Sánchez ha publicado dos volúmenes sucesivos sobre la vida de las pandillas Chicago-riqueñas que constituyen su propia biografía sobre la vida de los Latin Kings en Chicago. El primer volumen, My Bloody Life: The Making of a Latin King (2000), es un retrato vívido de lo que significa crecer en un barrio pobre puertorriqueño. Obsesión sexual, lealtades y traiciones ofrecen uno de 
los recuentos más impresionantes escritos por un ex-pandillero. En la secuela Once a King, Always a King: The Unmaking of a Latin King (2004), Sánchez retrata la vida ulterior del narrador y sus penosos esfuerzos por dejar en el pasado el mundo de las pandillas. Acerca de Sánchez, Bill Barillas observa:

\begin{abstract}
Sánchez, cuya madre lo trajo de niño de Puerto Rico a Chicago, para alejarse de un ambiente hogareño violento se une a los Latin Kings, conocida pandilla con frecuencia tan brutal con sus propios miembros como con sus rivales. Sus libros funcionan más como denuncia de la incapacidad de la sociedad para ayudar a niños desventajados que como relatos preventivos. Al mismo tiempo perpetrador y víctima del crimen, en verdad Sánchez no escatima esfuerzos por hablar sobre la violencia de las pandillas. (Barillas en manuscrito)
\end{abstract}

Ambos volúmenes constituyen uno de los recuentos más vívidos de la cultura de las pandillas que se haya escrito hasta la fecha, con la misma sensación de cotidianidad y asfixia que emana del vivir en los pobrísimos barrios puertorriqueños de Chicago. Como parte del proyecto de historia oral Chicago-riqueña de la Universidad de De Paul, otras narrativas de este tipo (incluyendo una biografía largamente esperada del Latin King Cha-Cha Jiménez, convertido en reformador comunitario) supuestamente en preparación, prometen dar nuevas perspectivas históricas sobre las pautas de criminalidad que persisten a pesar del surgimiento y éxito de muchos intelectuales estadounidenses-puertorriqueños de la generación actual. Se cree que Rubén Cruz, el chicago-riqueño culpado de un homicidio con connotaciones sexuales pero absuelto después de pasar varios años en prisión, está preparando la historia de su vida.

Dicho esto, uno de los escritores chicago-riqueños más prolíficos e importantes nacido en Chicago ha sido el poeta y dramaturgo Rane Arroyo, de escaso contacto con el mundo pandillero y su comunidad debido a su trabajo de profesor en Youngstown y Toledo, Ohio. De Arroyo, Bill Barillas señala:

Los padres del poeta y dramaturgo Rane Arroyo (1954) se conocieron en Chicago, llegados de Puerto Rico en busca de trabajo. Vivieron en Lincoln Park y otros vecindarios del norte, pero se trasladan a los suburbios del oeste de Chicago cuando el futuro escritor es todavía adolescente. En su tesis doctoral presentada en la Universidad de Pittsburgh, Babel USA: A Writer of Color Rethinks the Chicago Renaissance (1997), Arroyo muestra cómo los líderes de este movimiento sólo fueron admitidos en el canon después que los críticos dejan a un lado sus concepciones políticas en favor de asuntos estéticos, y compara la recepción crítica que recibieron en relación a la de sus contemporáneos latinos/as. Además de varios cuadernillos, Arroyo ha publicado tres volúmenes: The Singing Shark(1997), Pale Ramón (1998), y Home Movies of Narcissus (2002). Con frecuentes alusiones a la 
cultura popular y la cultura literaria, estos libros reflejan la compleja identidad de Arroyo como homosexual, puertorriqueño, profesor y escritor. Estas dimensiones personales convergen en el medio-oeste, particularmente en Chicago, ciudad que Arroyo todavía percibe como su casa aunque vive actualmente en Ohio. Su obra cuestiona nociones anticuadas del carácter del medio-oeste norteamericano. Dice en su poema "Being: An Essay on Being a Midwestern Writer" (en Midwestern Miscellany 30. Otoño 2002, xx-xx), "Un latino gay que ayuda / a un estudiante heterosexual a escribir un poema de amor / para 'su mujer' no aparece en los panfletos - ¿ ¿Por qué no? Es una descortesía que Hart Crane / no me haya visitado - él, que ahora viste / el Mar Caribe y yo, su Ohio" (xx). Además de su poesía, Arroyo también ha escrito varias obras de teatro, algunas de las cuales fueron representadas en Nueva York, Los Angeles y otras ciudades. Es también director de escritura creativa en la Universidad de Toledo (Barillas en manuscrito). ${ }^{6}$

Arroyo y al menos algunos de los artistas ya mencionados, deberían ser objeto de un estudio más amplio. Sin embargo este ensayo se centrará en adelante en el corazón de la poesía chicago-riqueña, la obra de David Hernández y el grupo que surge en 1977 con el número Nosotros de la Revista Chicano-Riqueña, que puso en primera plana a la poesía chicago-riqueña y la convirtió en parte esencial de la escritura de Chicago, del medio Oeste y de la escritura Latina en los EE.UU.

\section{LA EMERGENCIA DE LA ESCRITURA ÉTNICA CHICAGO-RIQUEÑA}

Para nuestro propósito, el contexto de la emergencia de una literatura étnica puertorriqueña-estadounidense específica en Chicago surge de condiciones de marginalización y alienación económica y social que generaron los disturbios de Division Street o alzamientos de 1966, que condujeron a la formación de nuevas organizaciones y grupos que buscaban generar desarrollos positivos en la comunidad puertorriqueña (Padilla, Latino 2; asimismo Padilla, Puerto Rican 117-143). Junto a ABC, ASPIRA y otras organizaciones comunales, también se desarrollaron grupos

\footnotetext{
6 Barillas agrega además una nota bibliográfica que merece ser citada: "Algunos comentarios sobre la poesía de Rane Arroyo incluyen una entrada de Glenn Sheldon sobre el escritor en David William Wallace, Latin American Writers on Gay and Lesbian Themes: A Bio-Critical Sourcebook (1994): 43-46; el comentario de Naton Leslie sobre Pale Ramon que apareció en Ohioana Quarterly 54 (Invierno del 2000): 316-17; y la reseña que hace Rigoberto González de Home Movies of Narcissus, "Expounding on Myth", en El Paso Times, 29 de Septiembre del 2002: 4F. En "The Already Browned Skin Of 'American' Modernism: Rane Arroyo's Pale Ramon” (en Midwestern Miscellany 30 [Otoño del 2002]: xx-xx), María DeGuzmán sostiene que Arroyo revisa la conciencia del Nuevo Mundo de Wallace Stevens y otros modernistas. Los ensayos de Arroyo están guardados en el Centro de Estudios Puertorriqueños en Hunter College". Desde que Barillas redactó este comentario, Arroyo ha publicado al menos otras dos colecciones (2005a y 2005b). Probablemente sea, de hecho, el poeta chicago-riqueño más importante y más prolífico.
} 
de enseñanza secundaria, universitaria y centros comunitarios que veían la expresión cultural al menos como una dimensión de su trabajo. El surgimiento de proyectos de publicación colectiva es claramente parte de esta historia.

Desde 1971 hasta su desaparición en 1975, The Rican: A Journal of Puerto Rican Cultural Expressions, publicado por Samuel Betances con base en Chicago, produjo artículos seminales en torno a la isla de Puerto Rico, su historia y experiencias de inmigración. Sus artículos incluían algunos poemas, primordialmente aquellos escritos por jóvenes chicago-riqueños, muchos de los cuales estaban también involucrados en las nuevas organizaciones sociales (Carmelo Romero llegaría a dirigir ASPIRA), mientras otros se hicieron miembros de organizaciones de arte comunitarias tales como The Workshop y ALBA (The Association of Latino Brotherhood of Artist), escritores que luego aparecerían en la antología Nosotros. En esta última categoría se encontraban David Hernández, Julio Noboa, Carmelo Romero y Emma Iris Rodríguez; mientras Chico Rivera y Shabazz Pérez escribían poesía exclusivamente para The Rican. Algunos de estos escritores, sobre todo Hernández, fueron los primeros chicago-latinos que aparecieron en las páginas de la Revista Chicano-Riqueña. Evidentemente, el eslabón fundamental entre estas dos publicaciones fue el formado por los poetas de The Rican, que encontraron su espacio en el número Nosotros de la Revista Chicano-Riqueña.

Si hasta la aparición de estas revistas muy poca gente había escuchado hablar de los "poetas hispanos de Chicago" o incluso de los "hispanos de Chicago", ahora la latinidad de Chicago iba a florecer con una acentuada definición de latinidad y un nuevo empuje. Nosotros es esencial para esta historia porque reunió a poetas en una revista latina de distribución nacional y porque sacó a relucir el talento puertorriqueño en una ciudad que, en términos latinos, era vista fundamentalmente como mexicana. Mientras que Revista había proyectado a algunos poetas y artistas de Chicago en sus inicios, ahora, con el número de Nosotros que presentaba a diez poetas latinos y a varios artistas visuales, la poesía y el arte chicago-latino y especialmente puertorriqueños finalmente pasan a formar parte de la escena nacional.

Nosotros articuló específica y conscientemente la perspectiva latina pannacionalista de Chicago usando el lenguaje militante de la época y abordando temas que hasta hoy día resultan esenciales:

Somos los poetas y artistas latinos. Como boricuas y chicanos hemos luchado por autodefinirnos y borrar los estereotipos impuestos en nuestros espíritus por las fuerzas de la opresión. Las comunidades latinas de América han dicho “ßBasta/Enough!” Nunca más los latinos de los EE.UU. serán identificados y estereotipados con imágenes que dicen cómo deberían actuar los puertorriqueños, cubanos, mexicanos, vistos a través de los ojos del mundo. Nosotros mismos nos definiremos. Nosotros decidiremos quiénes somos y cómo seremos. Nosotros 
mismos ejercemos el derecho de expresar nuestra identidad de manera tal que no haya explotador que pueda confundirnos y usarnos... Nuestra poesía y nuestro arte nacen del amor, del sufrimiento y de cada experiencia que deleita y atormenta a nuestro pueblo. Nosotros Somos los magos que tejen sortilegios gloriosos de imágenes pensadas, representantes de las vidas, humores, luchas y esperanzas de la gente que puebla los barrios Latinos de Chicago. Imprimimos un arcoiris de pensamientos y sentimientos que van desde los tonos más oscuros de la ira y la amargura a las fantasías y sueños más brillantes... Hablamos con las voces de un arcoiris subterráneo que comienza a asomarse desde los precipicios del racismo; porque nosotros no queremos eliminar sino armonizar nuestras raíces afro-indio-hispanas y nuestros hijos de cada color serán ejemplo de hermandad para la humanidad entera (Nosotros 1977: 1)

¿De dónde venían los poetas de Nosotros y hacia dónde iban? ¿De qué manera eran representantes típicos de su momento, o por lo menos de la experiencia chicagoriqueña de ese momento? ¿Hasta qué punto son la culminación de desarrollos anteriores y anticipos del futuro? Para explorar la poesía chicago-latina y chicagoriqueña estudiaremos la antología y los poetas de Nosotros en relación a las fuerzas que intervinieron en su creación. Es decir, usaremos esta publicación como punto de partida para explorar la forma en que el pasado social y literario de los poetas latinos de Chicago conlleva no sólo a un nacionalismo, sino a perspectivas que se desplazan más allá de él hacia una visión de Latinidad y más lejos aún, hacia el internacionalismo como posibilidad de una futura coalición multi-racial. Esta aproximación nos dará una visión encapsulada de algunas de las dimensiones claves de la historia de la literatura puertorriqueña en Chicago.

\section{NOSOTROS Y OTRAS DIMENSIONES PUERTORRIQUEÑAS}

La colección Nosotros es una representación diversa de la vida chicagolatina desde la perspectiva de los jóvenes puertorriqueños (con la excepción de la escritora chicana Yolanda Galván y el mexicano Rubén Sánchez ${ }^{7}$ ) quienes en su mayoría se han vuelto cada vez más resistentes frente a los problemas creados por la discriminación racial y cultural en sus comunidades, su ciudad y la isla de sus

\footnotetext{
7 Nicolás Kanellos añade que Juanita Jaramillo de Nuevo México tuvo parte en Nosotros y agrega que "Ana Castillo tuvo mucho que ver con la producción de esta antología, aunque no aparezca su obra en ella. De hecho, creo que por aquel tiempo ella salía con Chico Rivera" (NK). Chico Rivera era hermano de Salima Rivera; y como Salima Rivera me dijo una vez, los problemas de Castillo con Chico ocasionaron el rompimiento definitivo de las dos mujeres. En efecto, yo argumentaría que con excepción de David Hernández y Frank Varela en su relación con los escritores chicanos de $\mathrm{MARCH}$, el altercado fue decisivo para ahondar la división entre los escritores chicago-chicanos y chicago-riqueños.
} 
padres, y que exploran a través de su poesía posibles fuentes de oposición a nuevos efectos negativos. Escritos en español e inglés, los poemas de estos autores expresan orgullo por su herencia cultural y lealtad y amor por la isla a la que consideran su patria. Todos se rebelan contra la situación en la que sus padres y ellos mismos se han visto sumergidos: la injusticia que gobierna su miseria y su dolor, la experiencia de abandonar su patria, la cruel realidad de su vida en los barrios marginales, las drogas y la violencia que se han convertido en parte de su cotidianidad y contra la cual se rebelan.

Cabe destacar que este volumen es el producto de jóvenes brillantes que han experimentado las peores situaciones de la diáspora chicago-riqueña y que estuvieron involucrados en programas sociales y culturales para mejorar esa situación. Sometidos a un desempleo endémico y a las peores condiciones de vida de la ciudad, la juventud puertorriqueña se entregó a las pandillas, la droga, el crimen, a grupos independentistas y a programas de apoyo popular. No así los poetas. Muchos se volcaron a la poesía y a cualquier trabajo cultural que contribuyera a transformar la situación puertorriqueña. Para ellos su poesía es una cuestión de cháchara, danza, ritmo, sonidos callejeros, líneas descuidadas que rasgan la página impresa. Paréntesis y guiones comunican el tortuoso proceso de la creación poética. Los poemas a menudo bilingües pero no siempre "correctos" en ninguna lengua, luchan por expresarse, por decir lo que quieren, a veces con éxito, otras no. Sin duda esta poesía está influida por la escritura negra y nuyoricana contemporánea, aunque no todos los poetas se parecen en contexto y estilo. Por un lado están las ironías simples de Matías, en apretados poemas que apuntan a situaciones injustas que sufren los latinos y que cuestionan tanto el orden social como el divino. Estilísticamente más ambicioso en sus bilingüismos, ritmos y puntos de ataque, Eduardo Figueroa Condes recuerda a las mujeres campesinas que lo ayudaron en Puerto Rico y su propio trabajo en los campos de Nueva Jersey, es decir, rinde homenaje a ejemplos claves de su pasado puertorriqueño para que lo ayuden en su lucha futura.

César Quiñones, que escribe sólo en español, lamenta que algunos hombres y mujeres puertorriqueños hayan traicionado o distorsionado su conducta para sobrevivir. Para Quiñones, Carola canta al sonido de la radio y de la calle, atrapada en un mundo de consumismo y escapismo (encerrada en un mundo de música latina como evasión más que como confrontación), canta pero no sabe, "Carola canta y no sabe... no lo sabe, no lo sabe." En otro poema, una monja repite "bla, bla, bla", y en otro "tú no eres tú,... tú no existes". En muchos de ellos la gente no es lo que parece, o desaparece, o no puede desaparecer porque ha dejado de existir o quizás nunca existió. Y sin embargo, en el poema " 2 x 2 " se encuentra la nueva mujer, la que lleva una guerrera dentro de ella. La nueva mujer puertorriqueña espera nacer en el desierto y el infierno de la vida del barrio de hoy. 
Emma Iris Rodríguez habla, quizás con demasiada claridad, de la peor pobreza en la comunidad puertorriqueña:

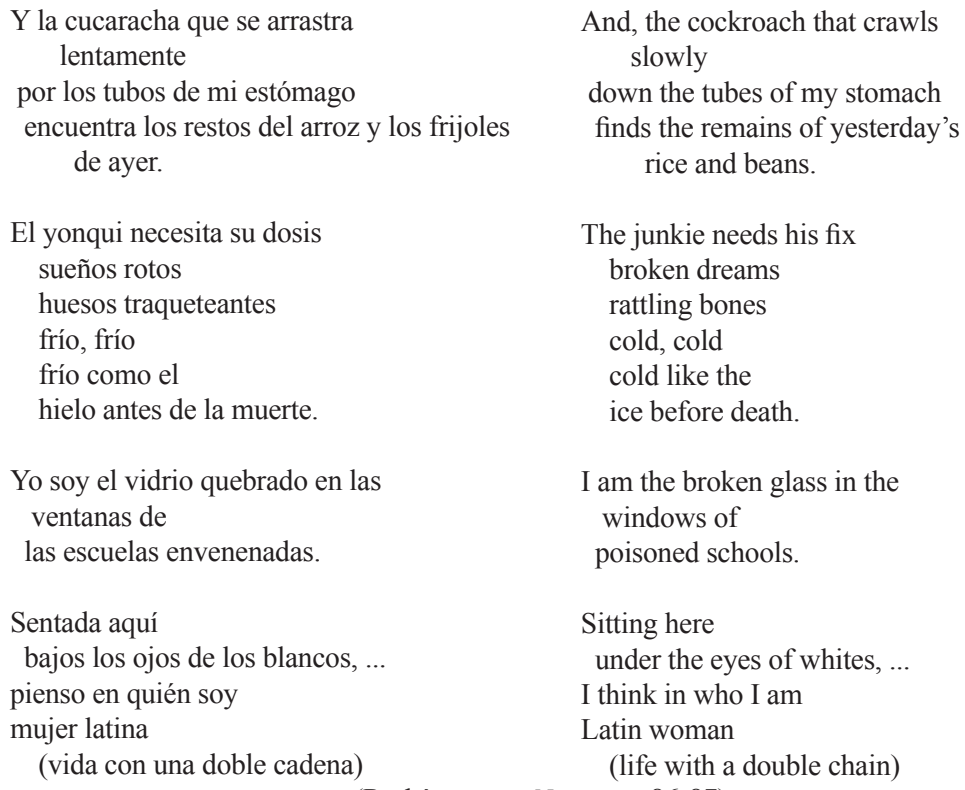

And, the cockroach that crawls slowly

down the tubes of my stomach

finds the remains of yesterday's rice and beans.

The junkie needs his fix broken dreams rattling bones cold, cold cold like the ice before death.

I am the broken glass in the windows of poisoned schools.

Sitting here under the eyes of whites, ...

I think in who I am

Latin woman

(life with a double chain)

(Rodríguez, en Nosotros: 86-87)

Unos pocos años antes, en "Tuley Products," una contribución a The Rican (II [1 octubre 1974]: 62), Rodríguez había reflexionado amargamente sobre el sistema educacional para los puertorriqueños durante la era Daley:

\author{
Año tras año \\ Los niños hispanos se convierten \\ EN \\ Pandilleros ruidosos, traficantes de drogas, \\ Alborotadores, merodeadores nocturnos. \\ Devorados de 8 a 4 \\ Por brutales trabajos de fábrica \\ Acosados por órdenes de desalojo \\ Perseguidos por tribus de cucarachas \\ Rodeados dentro de los sonidos latinos, \\ Bacardi, sueños felices colmados de vino \\ de \\ 'Nunca volver a Georgia' \\ Es decir, nunca irse, siempre morir
}

Year in, year out

Spanish children grow

INTO

Gang bangers, drug pushers,

Street hangers, night walkers.

Devoured by monstrous

8 til 4 factory jobs

Haunted by eviction notices

Chased by cockroach tribes

Enclosed within Latin sounds,

Bacardi, happy winefilled dreams

of

'I never go back to Georgia'

Which means, never leave, always die 
Y la única cama que tendrán

alguna vez

En Puerto Rico es un lecho de muerto.
And the only crib they will ever

own

In Puerto Rico is a death crypt.

En Nosotros, buscando imágenes todavía más fuertes, Rodríguez parecería acorralada en la eterna queja del gueto. Quizás por eso busca otras temáticas, otros modos de tratar con los problemas que la consumen. En consecuencia, se embarca en un viaje imaginario anticipando el de Sandra Cisneros, una de las escritoras latinas más reconocidas de Illinois, quien para abandonar sus ataduras, se libera de la depresión del gueto internándose en el futuro. Dejamos atrás el prosaico mundo de la falta de dinero, de noches de frío y hambre, de lugares y miedos del barrio para entrar en un mundo poético del tiempo y del espacio. Volvemos a la isla, incluso vamos al África. Pero (y he aquí el problema) la isla es el paraíso convencional de los recuerdos infantiles; África es el sitio cliché de los tambores sensuales, rituales antiguos, la danza primitiva, la sangre negra pura corriendo por las venas y encendiendo las pasiones de los hombres. ¿Es que no hay nada en nuestras realidades de Chicago que apunte hacia alguna genuina trascendencia de sus miserias?

Carmelo Rodríguez ofrece otro tipo de afirmación de negritud. Señalando a los Latin Kings y preguntando “¿dónde está nuestra nación?” explora la dimensión africana de la salsa, la dimensión latina del jazz, y las fuentes que vinculan a Puerto Rico con el resto del Caribe. En orgulloso desafío al intento de identificar a los puertorriqueños con una imagen racista blanca de los negros, escribe:

$\begin{array}{ll}\text { el hombre } & \text { the man } \\ \text { no ve } & \text { sees no } \\ \text { diferencias } & \text { differences } \\ \text { entre } & \text { between } \\ \text { nosotros } & \text { us } \\ \text { en español } & \text { in spanish } \\ \text { en inglés } & \text { in english } \\ \text { somos negros } & \text { we are niggers } \\ \text { debemos ser controlados } & \text { we must be ruled } \\ \text { o } & \text { or } \\ \text { destruidos } & \text { destroyed } \\ \text { su nación lo exige } & \text { his nation demands it } \\ \text { su nación lo demanda } & \text { his nation demands it } \\ & \\ \text { dejemos } & \text { let us stop } \\ \text { de matarnos } & \text { killing } \\ \text { los unos } & \text { each } \\ \text { a los otros } & \text { other } \\ \text { dejemos } & \text { let }\end{array}$




$\begin{array}{ll}\text { que el } & \text { the } \\ \text { espíritu } & \text { spirits } \\ \text { de África } & \text { of Afrika } \\ \text { nuestra } & \text { our } \\ \text { África } & \text { Afrika } \\ \text { Sea } & \text { be } \\ \text { el } & \text { the } \\ \text { espíritu } & \text { spirit } \\ \text { de } & \text { of } \\ \text { nuestra } & \text { our } \\ \text { nación } & \text { nation } \\ \text { ¡Hagamos morada! } & \text { let us build nests! } \\ & \text { (Romero, "Nest to be Built", en Nosotros: 102). }\end{array}$

Queda claro que la solución de Romero es romántica, otra falsificación exótica de las culturas negras caribeñas y africanas de los EE.UU., una visión limitada de la historia musical y humana. Pero si Romero malinterpreta la historia negra y reduce la salsa a sus componentes africanos, sus distorsiones son simplemente una reacción a otras soluciones impuestas. Si todo lo demás falla, si la unión sincrética de los oprimidos no conduce a la transformación de la vida misma, se arriesga a soñar con un ataque guerrillero y confirma, en la voz del África portuguesa: a luta continua (Nosotros 110).

No todos los poetas hablan la misma lengua, ofrecen el mismo mensaje, o han tenido la misma experiencia. Dentro de la misma órbita general de sus compañeros poetas, Julio Noboa, Jr., editor literario del Rican, nos confronta con algo diferente. He aquí un poeta empecinado en darle expresión al problema de la identidad que enfrentan los puertorriqueños de segunda generación en los años posteriores a 1967-68, pero cuya escritura no está tan directamente conectada al habla y la vida cotidiana. Nacido en el Bronx pero lejos de proyectar una voz nuyo-riqueña en su poesía, nunca estableció lazos con Puerto Rico en cuanto espacio de recuerdos y nostalgia como los otros poetas de Nosotros. Su poesía parece reflejar una perspectiva más amplia de la experiencia puertorriqueño-estadounidense en la medida en que busca y proporciona explicaciones para los sucesos que conforman la vida de los latinos. La suya es más bien una perspectiva mucho más histórica que involucra intereses económicos, políticos y religiosos. A diferencia de los otros poetas cuyas obras reflejan la vida cotidiana del barrio, los poemas de Noboa están elaborados a nivel conceptual, lo que revela un grado de educación formal que sobrepasa a los de sus compañeros. Si de algo sufre su poesía es de un tipo de abstracción defensiva, como si estuviera siempre luchando contra los estereotipos a fin de proyectar la imagen de un puertorriqueño bien educado y culto (incluso tiene poemas en rima). En uno de sus poemas se refiere a la continua explotación histórica de algunos grupos (de los cuales los latinos son sólo un ejemplo) por otros más poderosos, 
aunque ratifica el eventual triunfo del alma oprimida sobre el opresor. La verdad se encuentra en el conocimiento de la propia historia, y la libertad debe existir primero en la propia mente y en el propio espíritu. Noboa ve una solución a los problemas de la dependencia colonial de Puerto Rico y al estatuto de colonia interna de los barrios puertorriqueños en EE.UU. en la lucha por el derecho a la educación y al crecimiento espiritual y humano. Su poema "The Entire Scope of Humanity" señala las contradicciones de buscar la verdad a través de las instituciones creadas por aquellos que usan el conocimiento para controlar a los otros, no obstante sugiere que para los puertorriqueños no existe otra alternativa.

Noboa afirma su identidad puertorriqueña en el poema "Comiendo cerebro", y en otro, afirma sus raíces africanas, pero nos alerta contra aquellos puertorriqueños que se encierran en marcos estrechos reemplazando un estereotipo con otro o mostrándose orgullosos por lo que otros han tratado de imputar como atributos negativos de grupo (por ejemplo las raíces africanas). "Oración" muestra sus continuos esfuerzos por encontrar y entender su pasado puertorriqueño como la posibilidad de una identidad renovada, y en "Reencarnación" encontramos que aquella identidad se encuentra abrazando tanto la diversidad como la unidad puertorriqueña:

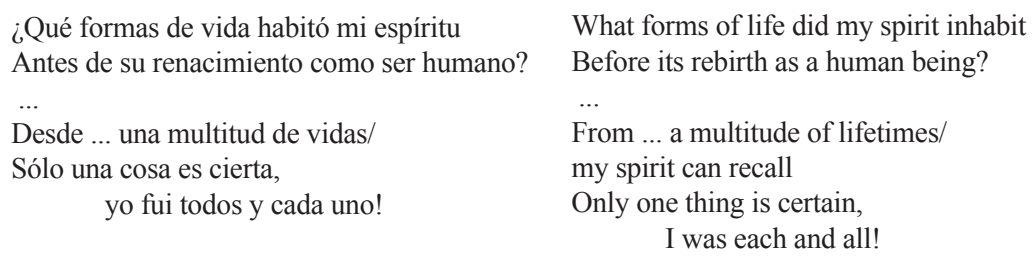

(Nosotros: 48).

Paradójicamente, su poema "Identity" parecería no tener contenido específicamente puertorriqueño; pero aún así es el poema que mejor expresa, en última instancia, la necesidad puertorriqueña de afirmación espiritual y cultural, incluso si otras formas de dependencia continúan:

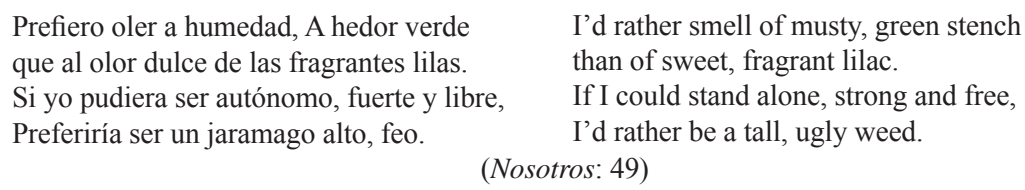

Finalmente, bajo esta luz, podemos leer el poema titulado "Survival of the Species" publicado en The Rican (I [May 4, 1974]: 51). Este poema revela los conflictos de Noboa con la expresión poética tanto como su importancia ideológica 
en el desarrollo de la poesía chicago-riqueña. Bien pudiera ser que debido a su distancia en dicción y concreción poética respecto a los estándares prácticos de Nosotros y, en general, de la mayoría de la escritura Latina urbana (como también de las normas poéticas dominantes y contraculturales) este poema no haya sido incluido en esa publicación. ${ }^{8}$ Asimismo estas cualidades o problemas podrían destacar el significado del poema como una afirmación ideológica típica de Noboa que en opinión de Félix Padilla tipifica todo el alcance de las aspiraciones chicago-riqueñas durante los años setenta (Padilla, Puerto Rican 190). En efecto, se puede decir que el poema expresa el marco valorativo desde el cual se percibían claramente las frustraciones con las realidades sociales y educacionales de los chicago-riqueños: el esfuerzo de moverse a través y más allá de un sentido de nación (aunque sin negarla), hacia una afirmación desafiante de los derechos puertorriqueños extensiva a la totalidad de la experiencia histórica humana.

De la semilla de la inteligencia Puede surgir y desarrollarse

La planta de la sabiduría

Sólo cuando las raíces estén

Incrustadas firmemente en el

Suelo fértil del Conocimiento,

Las hojas son iluminadas por la

Luz radiante de la Verdad

Y ambas se bañan en la

Lluvia purificante de la Experiencia.

Muchas semillas lejos del suelo fértil

Sin la bendición del sol y la lluvia

No llegan a ser plantas maduras, saludables,

Pero cuando el conocimiento alimenta, La Verdad ilumina y la Experiencia Vigoriza, la planta de La Sabiduría Crece hasta alcanzar la madurez,

Capaz de procreación y expresión.

Sólo cuando ha logrado esto,

La habilidad de crear, diseminar su

Semilla, con el espíritu en su interior

La planta de la Sabiduría pasa a ser un
From the seed of Intelligence

Could emerge and develop

The plant of wisdom

Only when the roots are

Firmly embedded in the

Rich soil of Knowledge,

The leaves are lit by the

Radiant sunlight of Truth

And both are bathed in the

Cleansing rainwaters of Experience.

Many good seeds not nurtured in rich

soil

Nor blessed with sunlight and rain

Never develop into mature, healthy plants,

But when knowledge nourishes,

Truth illuminates and Experience

Invigorates, the growing plant of

Wisdom blossoms into full maturity,

Capable of procreation and expression.

Only by this ultimate achievement,

The ability to create, spill its

Own seed, with the spirit within

\footnotetext{
8 Insatisfecho con mis conjeturas en este y otros puntos, Kanellos sugiere que llame a Noboa y le pregunte sobre los temas en cuestión (NK). Pero como estudiante de Lucien Goldmann y otros teóricos anti-intencionales, no creo que una llamada telefónica resolvería nada importante en relación a mi argumento; de hecho, a pesar del respeto que tengo por el trabajo empírico, creo firmemente, como académico teórico, en el poder y la necesidad de la extrapolación creativa y, sí, de la conjetura $(\mathrm{MZ})$.
} 
Eslabón en la cadena cósmica de la vida Y reivindica su derecho a la inmortalidad.
The plant of Wisdom forms a link In the cosmic chain of life And stakes a claim for immortality.

5. David Hernández y su poesía callejera de Chicago

El poeta central del grupo Nosotros, el escritor que alentó y sirvió de mentor y modelo a muchos de ellos, fue David Hernández, quien hasta el día de hoy destaca como personalidad y poeta importante en la escena Latina de Chicago.

Para la mayoría de los no-latinos de Chicago que no conocen nada de poesía latina, Hernández es la poesía chicago-latina. Él es el sempiterno representante, el que ha entrado por la puerta principal, el requisito talentoso en antologías citadinas, estatales, nacionales, nuestro poeta nuyorriqueño estilo-Chicago. ${ }^{9}$ Por supuesto que para algunos latinos y puertorriqueños, sigue demasiado desprestigiado, vinculado a la bohemia, a las drogas, al alcohol, al jazz, a la cultura afroamericana, a la cultura blanca. Él mismo es una paradoja: a un tiempo la institución de Chicago y modelo alternativo para los jóvenes pandilleros riqueños, pero a la vez muy anarquista, antisistema, beat, hippie y todo lo demás. Algunos se quejan por su rechazo a unirse a algún grupo político puertorriqueño específico, a pesar de colaborar e identificarse con las tendencias políticas más progresistas de Chicago. Otros se quejan de que toma los problemas puertorriqueños a la ligera. Pero el hecho es que Hernández ha asumido la posición tradicional del poeta desheredado. Sea aceptable o no, sigue la imagen de un Whitman o un Hart Crane puertorriqueño, cantando con ferocidad himnos democráticos y populistas a los mendigos, ebrios, vagabundos y pordioseras, a todos aquellos cuyos destinos son de alguna manera comparables a lo más desheredado de la diáspora puertorriqueña.

Lo cierto es que mediante su quimérica identidad poética ha sido capaz de representar a la mayor parte de la comunidad puertorriqueña. Ha tenido, por tanto, la "capacidad negativa" que Keats le atribuyó a un bien conocido poeta, que le ha permitido representar a muchos hombres si no a todas las mujeres. Hernández ha querido encarnar la voz masculina puertorriqueña de Chicago, A todo el espectro (pre-feminista) de temas literarios puertorriqueños en los EE.UU., desde la nostalgia por las raíces al hecho de crecer como latino en la parte peligrosa de la ciudad, a la lucha por la igualdad y el reconocimiento y a su deseo de superar el mundo puertorriqueño y latino en general. Todos estos temas están presentes en la colección de Hernández, auto-publicada con la ayuda de algunos amigos y significativamente titulada Despertando (1971).

9 Por ejemplo, Hernández es el poeta chicago-puertorriqueño que apareció en Barradas y Rodríguez, ed., 86-9. 
Hasta donde puedo apreciar, Despertando es la primera colección de poesía de un latino de Chicago. No extraña que apareciera el mismo año en que nació The Rican y en la víspera del nacimiento de la Revista Chicano-Riqueña. El título deriva del canto nacionalista Despierta Boricua, defiende lo tuyo. El estribillo se escuchaba constantemente en los barrios puertorriqueños de Chicago, especialmente en la década del setenta. Está también presente en los poemas que aparecen en la antología Nosotros y en los últimos trabajos de Hernández. El volumen es muy desigual (casi todos los mejores poemas, los más logrados, están en las primeras páginas del libro) y no sólo anticipa la mayoría de los temas de Hernández sino también sus principales características como escritor. Debemos, sin embargo, ser prudentes al observar tal desigualdad porque, como muestra su primer libro, el arte de Hernández se propone a sí mismo como un manifiesto virtual de improvisación creativa.

Apesar de las repetidas reescrituras de un mismo poema año tras año, Hernández insiste tanto por medio de la forma como por su expresa declaración, en el estatuto inviolable y esencial de la inspiración y la espontaneidad. Puesto que inherente a su arte es la irreverencia ante la poética académica, su estrategia consiste en crear un poema aparentemente desprolijo incluso cuando el efecto final resulte altamente calculado. Los poemas son escritos como variantes de una melodía o un grupo de acordes no expresados, en función de un diseño rítmico dado, con rimas internas $\mathrm{y}$ otros mecanismos poéticos que crean una impresión de forma constantemente transgredida, de manera sutil y burlona, como si la disonancia o interrupción rítmica reflejara una función de la vida o las confusiones de la sociedad, de sus desequilibrios y discordancias. Desde 1972 y por varios años, Hernández habitualmente leía/ representaba sus poemas con su grupo musical, Los Sonidos de la Calle o Street Sounds (generalmente acompañado de bajo, guitarra, congas, y otra percusión) en un sincretismo de jazz latino complementario y paralelo al proceso de mezcla de sus propios poemas. Y dado que Los Sonidos proveían la imperceptible corriente subyacente de música y ritmo, el efecto de los artificios estilísticos de Hernández se hacía evidente. El verso sin pulir en contraste con notas y acordes mucho más definidos, la disonancia, interrupción e inseguridad de uno de los dos sistemas culturales en juego además de sus esquemas ideológicos se manifiestan en toda su expresión. Quizás en esto consista el desafío de Hernández como escritor: muchos de sus poemas no funcionan tan bien sobre el papel como ante un trasfondo musical o simplemente leídos en voz alta. Parte de este problema es el de la palabra hablada y el performance; sin embargo en la década de los ochenta las producciones teatrales basadas en sus poemas resultaron efectivas incluso cuando el autor no leía directamente sus poemas. 
Las referencias a la música y al teatro demuestran las amplias orientaciones artísticas a veces encubiertas por las actitudes y temáticas populistas de Hernández. Por eso, cuando se le pregunta acerca de su inspiración, su referencia no es la música ni el teatro sino la escultura: "La poesía es la herramienta para cambiar el idioma inglés". Dice:

\begin{abstract}
intento destruir el lenguaje de los tontos fascistas y reconstruirlo para todos nosotros. El escultor blanco Julián Harr me llevó a su estudio en 1963 y me convertí en su aprendiz. No como escultor sino como poeta. Mirándolo tallar y moldear, crear a partir de lo informe, fue como aprendí el oficio de la poesía. Mi vida se desarrolló parte entre mi gente y parte en el estilo bohemio de la contra-cultura que representaba Julián. De ahí en adelante mi círculo de artistas de todas las razas y orígenes creció cada vez más hasta que el infierno explotó y yo encontré mi cielo. ${ }^{10}$
\end{abstract}

Pero después de este viaje al interior de la escultura, su referente parece dirigirse a la música:

Soy producto del juglar africano y la antena de la raza. La poesía es importante para mí porque llena el espacio entre los latidos (heart-beat) de mi corazón.

Nacido en 1946 en Cidra, Puerto Rico, Hernández llegó a Chicago en 1955 con sus padres, dos hermanos y una hermana. Como nos dice uno de sus poemas, sus padres eran muy pobres y la familia vivió principalmente en el barrio norte puertorriqueño. Asistió a tres escuelas distintas, fue degradado, desplazado y eliminado del sistema educativo porque no hablaba bien el inglés. A finales de los sesenta ya era miembro de la contra-cultura, estaba inmerso en la droga, el jazz, y (si le creemos a su poesía) en excesos hetero-sexuales. Mientras dedica su obra a todos aquellos a quienes puede llamar su comunidad, esboza atropelladamente sus poemas, medio mutilados, medio formados, con elementos tomados de aquí y de allá, impresiones sobre el sistema de transporte de Chicago, viñetas sobre las luces nocturnas de Chicago y algunos recuerdos personales que, considerados como un todo, podrían conformar una pequeña novela, versión en miniatura de la vida latina como los Family Installments de Eduardo Rivera (1983). De este modo, Despertando empieza en Puerto Rico con un niño que sube a una montaña con una cubeta de hojalata llena, y detrás de él, unos perros que ladran y otros que cantan. Luego se lo ve en un avión, aterrizando en el aeropuerto de Midway. Un niño orgulloso color café, que anticipa las sonrisas de los norteamericanos, cuando llega es golpeado por el viento de Chicago, y a medida que el libro se desarrolla,

${ }^{10}$ El comentario de Hernández surge de sus respuestas escritas en 1985 a mi cuestionario del mismo año. 
lo vemos empezando a conocer su nuevo mundo. Hay poemas sobre jóvenes y ancianos puertorriqueños, sobre marginales color café, negros y blancos. Hay un hombre puertorriqueño que pierde sus dedos y su trabajo, deja su orgullo a un lado y busca asistencia social; un adolescente puertorriqueño que no tiene otra opción que enrolarse en el ejército, una mexicana que sufre, una prostituta, una anciana comiendo sola. Las memorias y las viñetas consideradas entre sus mejores trabajos, son retratos duros, profundamente sentidos de una realidad cruel e injusta.

Características similares se encuentran en el material de Nosotros de 1977. En dos poemas que más tarde entretejería como parte de un canto que le confiere identidad, el poeta entona:

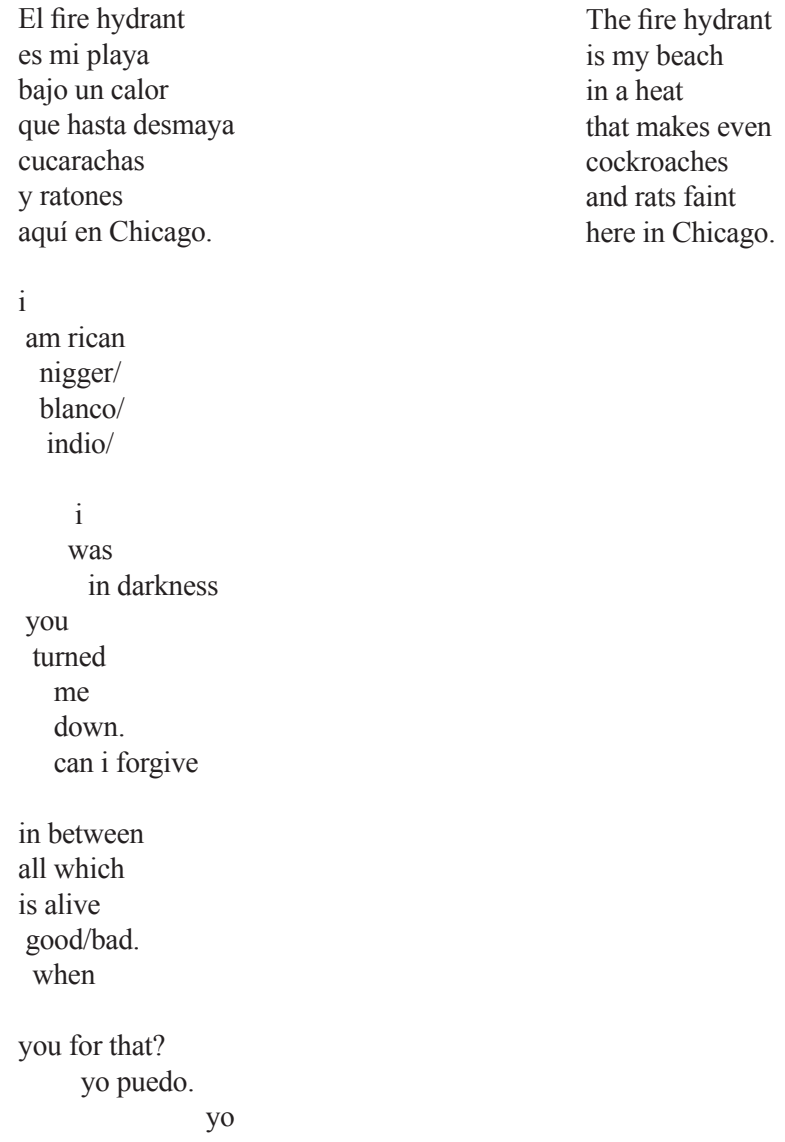

The fire hydrant is my beach in a heat that makes even cockroaches and rats faint here in Chicago. 
(Hernández, "Me la Buscaré” y "White Statue" en Nosotros: 3-4).

Algunos de los poemas largos que le siguen están lejos de ser sus mejores composiciones, sin embargo uno de ellos, "Tecata" (Nosotros: 4), nos muestra un crudo retrato de cómo los valores tradicionales puertorriqueños son embestidos por las pesadillas urbanas que llevan de la droga a la muerte. Y finalmente, en "Fama," tenemos otra larga tirada de poemas-catálogo que constituyen su mayor éxito:

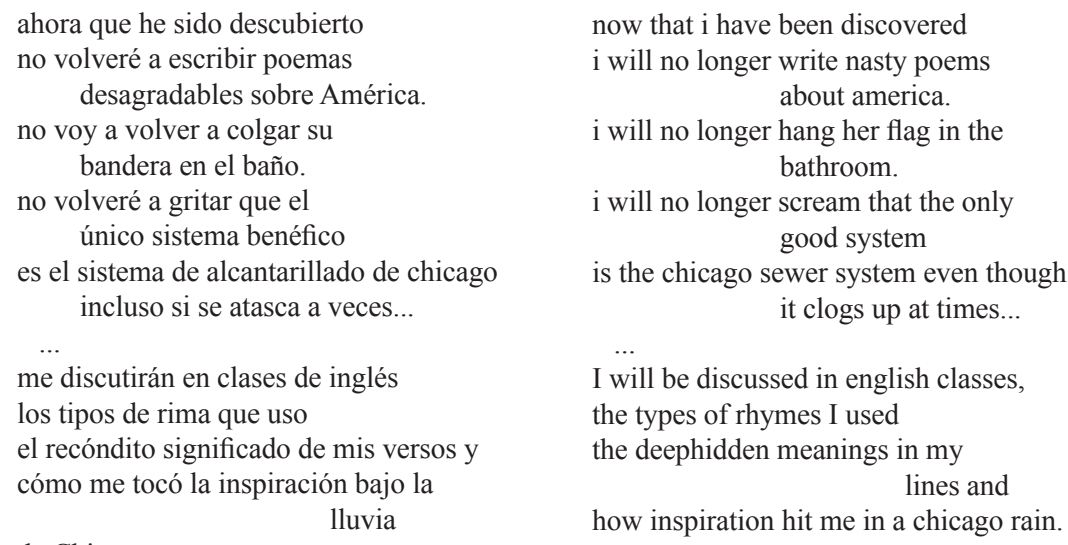

de Chicago.

(Nosotros: 11-12).

En un poema mucho más reciente, Hernández dice: “Quiero ser un poeta de verdad/para poder participar en discusiones poéticas”. Ahora que Hernández es más o menos famoso (al menos en Chicago), estamos analizándolo y evaluándolo. En una significativa afirmación señala que "al ser de Illinois y Chicago, el entorno, el lugar de la ciudad, influye poderosamente en las imágenes y el ritmo de la poesía... En una ciudad racista," añade: "los poetas latinos deben ser más sutiles, más duros y luchar sin cuartel contra los artistas débiles". En Despertando la situación a veces lo lleva a la ira:

\author{
No me importa quién eres \\ o por qué \\ aquí yo soy no de los estados unidos \\ de amerikkka en \\ chicago.
}

I do not care who you

are or why

here is me from not the united states

of amerikkka in

chicago. 


$\begin{array}{ll}\text { mugre hedor } & \text { dirt stench } \\ \text { mierda putas } & \text { shit whores } \\ \text { wiskey vino } & \text { wiskey wine } \\ \text { sudor orines tiempo } & \text { sweat piss time } \\ \text { yerba árboles cielo } & \text { grass trees sky } \\ \quad \text { (“Él,”en Despertando: } 52) & \end{array}$

La otra cara de este ataque violento es la del Hernández populista y sentimental, enamorado del amor, efusivo y empalagoso. Si el amor y la verdad han de prevalecer sobre un mundo de odio y mentiras, que la victoria sea obtenida con esfuerzo, de manera que tenga una genuina equivalencia con los problemas que enfrentamos en la vida. Si David Hernández encuentra la salida al dilema de ser un "moreno de Chicago" en el vientre de tiburón de los EE.UU., si nunca se olvida que muchos de sus hermanos no han encontrado su propio camino, si esos hermanos son la verdadera fuente y la materia de su obra, ¿pudiera ser que en el proceso de encontrar su camino a través de la escritura, haya por momentos, llegado a identificar a los escritores o a su audiencia latina-blanca, consumidora-de-arte-yartistas, como a su verdadera hermandad?: "Vengo de una orgullosa herencia tribal de artistas: mercaderes-de-palabras", le canta hoy a su audiencia, en ocasiones mayoritariamente blanca, mientras le agradece la posibilidad de llevar a cabo su actuación y representar su trabajo.

¿Acaso la amargura de Despertando y los poemas de Nosotros se han convertido en conformidad? ¿Se ha ablandado demasiado Hernández? Esa parecería ser la conclusión al leer su pequeña colección Satin-City Lullaby (1987) o su colección Elvis (1995). Sin embargo, el efecto total de su performance desmiente cualquier impresión negativa (incluso algunos de los poemas de Satin-City Lullaby se escuchan mejor de lo que parecen en el papel). ${ }^{11}$

Muchos de los mejores poemas de Hernández quedaron disponibles en Roof Top Piper (1991), una atractiva publicación que presenta al poeta como un puertorriqueño descendiente de Whitman al que la traumática bofetada original del viento de Chicago le descubrió las fuerzas que condenan a los riqueños y a tantos otros más a la pobreza, a la droga, a la pérdida de seguridad e identidad. Estos

\footnotetext{
${ }^{11}$ Comentando sobre este pasaje, el mismo Kanellos revela el poder y el valor de la conjetura basada en años de trabajo y compromiso en palabras aplicables a muchos nuyo-riqueños (aunque no a todos) y escritores: "Pienso que lo que realmente les pasa a los poetas autodidactas de la comunidad es que su falta de estudio y lectura no los deja crecer, de modo que se quedan en un nivel y se vuelven repetitivos, no pueden continuar experimentando y llegar más lejos en su desarrollo. Es muy parecido al síndrome folklórico, donde hay un género, un juego de temas, una función en la comunidad, pero no la necesidad de explorar nuevas formas y nuevas estéticas, porque en última instancia no es un problema de experimentación estética; sino más bien de comunicación y de poder decir cosas que otros en la comunidad no pueden expresar" (NK).
} 
poemas están llenos de humor, emoción y esperanza en lo que bien podría ser su texto definitivo, capaz de retratar los altibajos de la vida de los chicago-riqueños. Gran parte de este material ha sido llevado al mercado en su forma definitiva como performance en una grabación llamada Liquid Thoughts (1988). Las cintas revelan que lo que realmente mantiene vivo su trabajo es la ironía y el humor de su capacidad performativa, y no su sentimentalismo indulgente ni su ira, sino ese otro lado suyo que hace que él y su público puedan reírse ante el dolor y la fealdad. En uno de sus poemas narrativos más insólitos y encantadores, "Chicago Sun Times", poema de performance sin acompañamiento (en Liquid Thoughts, pista 3), cuenta cómo se siente tentado de robar el periódico de la puerta de un vecino pero que decide no hacerlo porque imagina, paso a paso, cómo este acto puede producir un sentimiento de rencor que podría culminar en un holocausto nuclear mundial. Sin ningún referente latino o puertorriqueño explícito y sin embargo profundamente enraizado en la tradición de Chicago, este poema habla cómicamente sobre un absurdo surrealista, espeluznante, en que nada puede darse por sentado, en que la espontaneidad sin cálculo es imposible y en que lo peor está siempre a punto de suceder. En semejante mundo, el refugio del amor íntimo y la consumación de ese amor en el poema se vuelven opciones peligrosas, poco modernas, románticas, sentimentales, pasadas de moda. Pero esas son las únicas opciones para este poeta eminentemente Riqueño/Latino a medida que construye su camino, sus giros y vueltas a través de los años.

\section{Salima Rivera y la construcción de la identidad PuertorriQueña/Latina}

Eliana Ortega esboza un modelo en el cual las escritoras puertorriqueñas se identifican con una madre borinqueña comunal, indígena, anterior a la Conquista y representada como Anacaona o Preciosa, para reafirmar un inherente sentido de matriarcado en relación a una familia tribal extendida, para luego proyectarse más allá de la posición alienada y oprimida de la mujer en el contexto de la dominación española primero como de la estadounidense más tarde.

Para demostrar su hipótesis Ortega recurre a la antología Nosotros y se concentra en una escritora que no hemos mencionado todavía: Salima Rivera, especialmente en uno de los poemas de Nosotros ("Ode to an Island"). Ortega señala que:

El "yo" lírico en ... el poema de Rivera... remite a un "nosotros" [en tanto]... discurso poético que surge de una identificación con la madre indígena, ... que trasciende la esfera puramente doméstica y se proyecta ... en una esfera histórico-políticanacional que [la poeta] rastrea hasta sus orígenes. Los hablantes maternos [de Rivera] no son ni mártires silenciosos ni tristes lloronas sino más bien rebeldes con una causa muy específica: liberación, pero no simplemente liberación individual, 
sino también liberación de su madre patria. Así las poetas puertorriqueñas que viven en los EE.UU. continúan con la tradición Anacaónica de la canción como voz de rebelión y acto liberador. A la vez que desmitifican el discurso patriarcal de la cultura dominante, estas poetas producen mediante un proceso dialéctico, un discurso poético dinámico, creando nuevos mitos que son a su vez, producto de las circunstancias de una cotidianeidad muy específica en cuanto mujeres latinas que viven en los EE.UU. (128-29)

Volviendo a la poesía de Rivera en Nosotros, Ortega muestra cómo la escritura de las mujeres puertorriqueñas manifiesta su ira "contra la situación de violencia y destrucción que caracteriza la vida de los puertorriqueños bajo el colonialismo estadounidense". En este contexto, muestra cómo Rivera en su poema "False Idols" de Nosotros, trivializa la idea de que "gobernar es destino del hombre", declarando su incredulidad ante deidades débiles (Ortega 131-32).

Este estudio recurre a la misma poesía de Nosotros para mostrar brevemente cómo el primer trabajo de Rivera proyecta primero una afirmación y luego una parcial rebelión feminista contra patrones de comportamiento típicos de los mitos patriarcales y nacionalistas. A continuación, el estudio aborda la obra más reciente de Rivera para sugerir cómo a través de la influencia de otras latinas ejemplares no-puertorriqueñas, Rivera madura en función de perspectivas generalmente más latinas, internacionales y feministas, con una poesía más fresca, más sincrética e individual que paradójicamente logra expresar con mejores resultados problemas centrales de la identidad nacional y femenina puertorriqueña y sus transformaciones en la actual vida americana. Por lo tanto nos proponemos señalar la construcción gradual de una identidad puertorriqueña en el contexto de la múltiple realidad latinoamericana de Chicago.

Con excepción de Hernández, Rivera fue la poeta mejor conocida del grupo Nosotros, de quien se podía decir que resumía y llevaba a sus últimas consecuencias las características que ya hemos discutido. Hija mayor de Luis y Florentina Rivera, nació en la pequeña ciudad costera de Isabela en Puerto Rico, el 19 de agosto de 1946 y llegó a los EE.UU. vía Salt Lake City el mismo año. Su padre fue empleado por la Anaconda Copper Mining Company hasta la huelga de 1948 que lo forzó a emigrar a Chicago donde encontró empleo en una fábrica textil, mandó a buscar a su joven familia y se estableció en el oeste de la ciudad. ${ }^{12}$

Como la mayoría de las mujeres puertorriqueñas de su generación, Rivera tuvo una limitada educación formal. Asistió a las escuelas técnicas y vocacionales Crane Technical y Richard Vocational y durante un año tomó clases en Columbia

${ }^{12}$ Los detalles y comentarios biográficos de Rivera están tomados de sus respuestas al cuestionario que le envié y que respondió en 1985. 
College. Fue en gran medida una poeta autodidacta que habiendo empezado como diseñadora gráfica le dio a su escritura un amplio sentido visual. Además, quizás por el hecho de haber sido criada algunos años por una familia mexicana, su obra quedó marcada no sólo por su experiencia como mujer puertorriqueña sino también como latina comprometida con su comunidad y con el mundo en general. Con el paso de los años trabajó con varias organizaciones comunitarias, entre ellas Casa Aztlán, el Movimiento Artístico Chicano, la Westtown Concerned Citizens Coalition y desde 1985, en la Oficina de Eventos Especiales de la Alcaldía. En los años 80 y 90, mientras vivía al oeste de la ciudad con su esposo, el artista chicano Oscar Moya, y su hijo, fue la primera escritora Chicago-riqueña que trabajó temas mexicanos y puertorriqueños, feministas y nacionalistas. Por esta y otras razones, es una figura esencial en esta historia de poesía latina emergente.

La sección de Rivera en Nosotros (53-63) comienza de manera más bien convencional, con una serie de poemas marcados por imágenes clichés de tambores tropicales, el "vientre fértil de la patria", la "raza orgullosa", etc. Le creemos cuando habla en contra de los puertorriqueños muertos en las guerras externas de los EE.UU: "Un humor envenenado de odio / me llena las venas cuando te veo despatarrado / sangrando en el abrasado suelo extranjero"; o cuando se queja: "silenciosamente me condenas mientras busco la libertad que tú desprecias", y luego, "sangre cadenciosa ... ruge por las ... venas" cantando sobre "bosques tropicales verdecidos y pechos bronceados". La presencia de Borinquen "persiste como el beso trémulo/ que una joven virgen dispensa/ sobre el ceño de su joven amante". El llamado a los puertorriqueños a que no olviden su tierra es conmovedor; igualmente sorprende la equivalencia de esa tierra con el amor. Sin embargo el mensaje no es una orden. Sus palabras no son los "dones magníficos" que reclama. La "Elegy" de Rivera se ve perjudicada por ritmos anticuados y gestos convencionales. Mucho mejor, su "False Idols", queda debilitado sin embargo por el primer verso. Con la aparición de "Contradictions" aumenta la calidad general de su trabajo con un tono más simple, claro, compungido, incluso quizás lúdico que expresa las antinomias básicas esenciales a la vida y condiciones de tantas mujeres. "Fruits of war" es también directo y conmovedor aunque no resulte original en sus imágenes. El pequeño poema "A Woman Alone", sin embargo, se lee como un fragmento de Safo, delicado y fino en su forma:

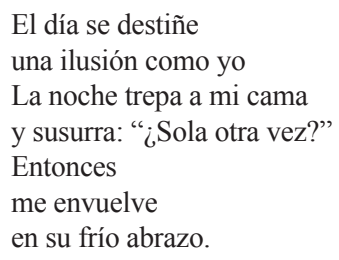

(Nosotros: 62)
The day has faded an illusion like me Night creeps in my bed and whispers: "Alone again?" Then covers me in its cold embrace. 
El dilema para la escritora puertorriqueña o latina es encontrar la forma de resolver sus problemas de opresión por los hombres sin terminar sola, sin romper totalmente con su base cultural. En "Home Again" la poeta dice que es capaz de trascender la noche solitaria para concentrarse en la belleza del amanecer. Pero el tema ya es conocido; el poema es inferior en calidad al anterior del que toma sustento, como lo es también el que le sigue, "The Silent Minstrel", que de hecho satisface la promesa del amanecer, pero más que por sus abiertos reclamos, por medio de su delicado y rítmico tejido de palabras que anuncian a una poeta con futuro:

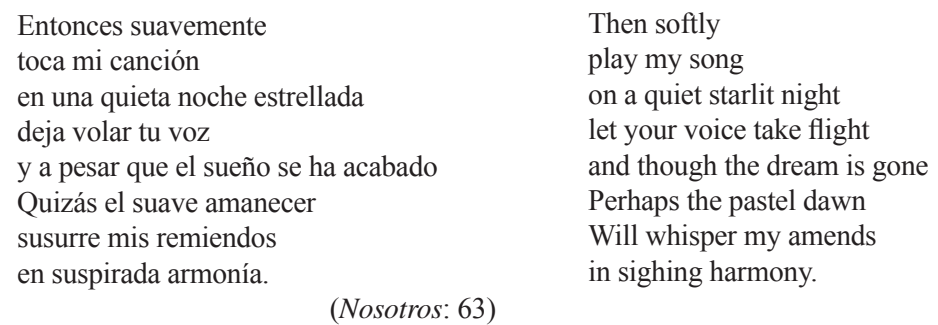

Esta es una poeta cuya obra a veces titubea, pero que no obstante alcanza momentos de intensidad, gracia y fuerza. En sus primeras obras, Rivera expresa su desengaño no sólo del amor personal, romántico, sino también del romance con la patria y la confianza en ella. Prisionera de un mundo que se ha autodefinido como la "tierra firme" de Puerto Rico, las mujeres puertorriqueñas enfrentan las contradicciones de las minorías femeninas norteamericanas con el agravante que surge de su nostalgia y atroz sentimiento de pérdida en el contexto de la "cuestión nacional" puertorriqueña. ¿Puede transformarse esto en algo productivo? Sólo cuando el amanecer se materialice en formas elaboradas de percepción y acción en el arte. Esto no es nada fácil de lograr, pero el trabajo de Rivera en Nosotros sugiere posibilidades y luchas futuras para decir con fuerza la verdad.

Durante los ochenta, cuando la mayoría de las escritoras latinas desarrollaban un discurso marcadamente femenino y personal, Rivera continuó publicando poemas enfocados principalmente en temas de conciencia política y social con referencia a las minorías de los EE.UU., además de preocupaciones internacionales latinoamericanas. Un poema como "Indio" (Revista Chicano-Riqueña 1981: 22) elogia el orgullo liberador de un pueblo oprimido. "The Crazy Women from Plaza de Mayo" (Third Woman 1982: 25) busca expresar su simpatía por las mujeres argentinas que arriesgaron sus vidas para exigir información sobre el paradero de sus hijos desaparecidos. "A Letter to a Friend in El Salvador" (Ecos 1982: 56) habla por aquellos que murieron en las luchas populares de esa nación. Los tres poemas muestran a una poeta cuyos horizontes formales y temáticos están en proceso de expansión. 
Quizás de mayor éxito que estos trabajos sean sus poemas de 1982 centrados en la ciudad, trabajos más cercanos a su propia experiencia: "Louie the Mongoose, Killer of Snakes" y "Pilsen" (Ecos 1982: 16 y 13-14 respectivamente).

Rememorando el eslogan de Nosotros, "We are the rainbow race", "Louie la mangosta" vive gracias al poder de sus convicciones y su dolor a medida que recuenta la historia de un nacionalista puertorriqueño:

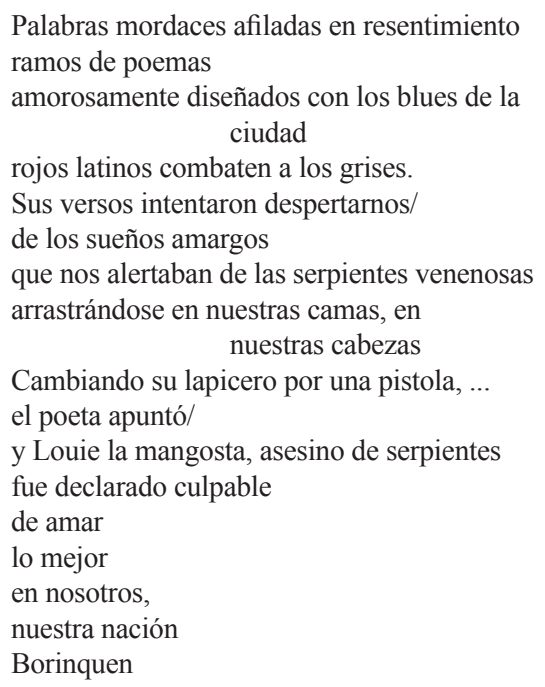

En cuanto a "Pilsen", aunque quizás desvalorizado por las referencias a un proyecto de modernización de la ciudad (Plan 21) completamente olvidado, habla de los actuales esfuerzos de aburguesamiento, al tiempo que evoca a la mujer puertorriqueña del mundo mexicano de Chicago. Aquí el intenso poder de la imaginería crea una estética virtual de poesía urbana:

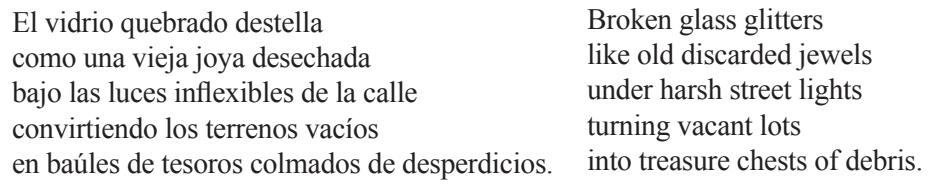

Después, en laúltima estrofa, "night surrenders to the gold streaks on the horizon" y los fragmentos deslumbrantes dan paso a un amanecer que revela paredes llenas de grafiti, murales y una epifanía virtual de la experiencia Chicago-mexicana: 
hombres en ropas oscuras

y mujeres pacientes se amontonan/

como quietas bandadas de pájaros negros

esperando que los autobuses/

los lleven al matadero. men in dark clothes

and patient women huddle/

like quiet flocks of blackbirds

waiting for the buses/

to take them to the slaughterhouse

Parece que las pacientes mujeres esperando su dosis diaria de explotación asesina no están tan alejadas de esas lloronas que invoca Eliana Ortega en el pasaje anteriormente citado. Y bien se podría argumentar que el conocimiento directo que tiene Ortega del mundo mexicano de Chicago y de la victimización de clase y género de las mexicanas-chicanas le ayuda a proyectar su emergente feminismo. Esto podría haber impactado directamente su poesía con la mediación de esa chicana impaciente, Sandra Cisneros, en cuyo taller poético City Songs de 1983, codirigido por el poeta afro-americano Reggie Young en el Centro Comunitario Puertorriqueño Ruiz Belvis de Chicago, participara Rivera.

Cualquiera sea la razón de esta trayectoria evolutiva, no parece accidental que en su contribución a la colección City Songs (Ecos 1983: 5-23) Rivera vuelva al tema de su patria y al proceso de enajenación cultural. El poema "There are no Ceibas in Chicago" es su evocación más madura y lograda de las raíces del pasado, tanto como de la compleja lucha de transplante e identidad latina en un mundo en el que la isla del encanto está siendo recubierta (y posiblemente enriquecida) por imágenes de Alicia en el anglófono país de las maravillas:

No hay ceibas en Chicago,
esos árboles gigantes en cuyas enredadas raíces
mi madre jugara de niña
lo llamaba el árbol del demonio.
De noche la entendí
mientras miraba los enormes nudos de madera/
escabrosas rajaduras en la cruda tierra encantada,
tropical conexión en el sueño de Alicia.
Arrastrándose sobre pies y manos,
alzando su familia de trapo.
Yo busqué el país de las maravillas
pero el conejo blanco se había ido/
tierra adentro
y el gato de Cheshire no hablaba Spanglish

En los ochenta, cuando ocupaba un puesto de mucha visibilidad en la Oficina de Eventos Especiales de la Alcaldía, Rivera publicó muy poca poesía. Mientras tanto su amiga Lillian Anguiano se ocupaba de reunir y procesar un corpus inédito. En este proyecto aparecieron algunos poemas bien logrados y audaces (poemas
There are no ceibas in Chicago, those great trees in whose tangled roots my mother played as a child She called it the devil tree. At night, I understood her meaning as I gazed at the enormous twists of wood/ jagged rents in the raw enchanted earth, a tropical connection into Alice's Dream. Crawling in on hands and feet, raising her ragdoll family. I searched for the wonderous land but the White Rabbit had moved/ to the mainland and the Cheshire Cat didn't speak Spanglish (Ecos 1983: 6) 
personales, poemas de ciudad: "Acculturation", "The Sub-Urban Pioneer", "Victor", "Summer Madness", "If the Shoe Fits...", "Erotica Sweet", "The Bag Lady", "Hard Times II", "Herstory"13) que fueron leídos en público pero nunca publicados. Estos poemas reafirman y profundizan algunas de las mayores preocupaciones de Rivera: patrones de adaptación latina, abandono, preservación y celebración de algunas de las peores tradiciones, tales como la bebida, el sexismo y la violencia. Se esperaba que cuando aparecieran estos poemas habría llegado el momento de anunciar a la poeta más importante surgida de la agonía chicago-riqueña de finales de los sesenta. Pero ese momento nunca llegaría porque, después de una larga y dolorosa lucha, Rivera sucumbió al cáncer en el año 2004. Al parecer, su libro de poesía ya nunca habría de ver la luz. Sin embargo, en base a los pocos poemas que había publicado, se puede decir sin temor a equivocarse que Rivera ha ofrecido a los lectores momentos memorables de un extenso poema afianzado en su experiencia personal y fertilizado por su experiencia multidimensional Chicago-Latina, que fue capaz de expresar a un conjunto social más amplio y presentar como testimonio algunos de los problemas y sentimientos cruciales para la diáspora puertorriqueña

\section{CONSIDERACIONES FinALES}

En 1974, precisamente cuando los chicago-riqueños empezaban a articular sus preocupaciones, el académico Frank Bonilla observó con respecto a la situación puertorriqueña:

La dialéctica de impotencia y porfiada resistencia, por más encubierta y difusa, es percibida como una fricción que hace trizas los lazos individuales y sociales, pero se le niega cualquier futuro de resolución política. Quizás estemos desarrollando un virtuosismo peligroso al documentar la postración, la inseguridad, la ambivalencia y el desconcierto ideológico dentro de nuestra propia gente dando muy poco valor a los signos contrarios que apuntan a una notable capacidad de supervivencia en un contexto de prolongada y radical ambigüedad. (Conferencia de Bonilla citada en Padilla, Puerto Rican 64)

Con los chicago-riqueños y los poetas de Nosotros podemos percibir tanto esta dialéctica de impotencia y terca resistencia como las esperanzas y frustraciones respecto a soluciones políticas apocalípticas. En sus obras, estos escritores muestran un creciente virtuosismo que documenta la postración, la inseguridad puertorriqueña. Sin embargo, en sus mejores logros, estos mismos escritores subrayan la capacidad de sobrevivir de los puertorriqueños, de convertir en productiva su difícil situación

\footnotetext{
${ }_{13}$ Este es un neologismo acuñado a fines de los sesenta que enfatiza la visión feminista de la historia opuesta a la historiografía convencional que se comprende como la historia escrita o contada por el sujeto masculino (Nota del Traductor).
} 
y de encontrar nuevas formas de crecimiento. Esta aspiración presente en muchos de ellos quizás haya sido articulada más directamente por Noboa; quizás de forma más amena, variada y detallada, por David Hernández quien, mejor poeta que Noboa o que la mayoría de los otros escritores de Nosotros, no solamente describe esta aspiración sino que a veces la lleva a cabo. Esta aspiración sumada a su realización permea también la obra de Salima Rivera.

La afirmación y suposición subyacente de este ensayo ha sido que la literatura puertorriqueña es en primer lugar, un espacio para la exploración y la fragua de un nuevo sentido de identidad y de nación frente a la pérdida, la desorientación y las identificaciones multi-étnicas y multi-latinas. El espacio de esta literatura se encuentra allí donde la colonia o el barrio puertorriqueño se relaciona con la ciudad, la isla, el Caribe, África y el mundo. En este contexto internacionalista (que muy concretamente incluye el problema de género y actitudes en transformación), la mayor contribución de la escritura Chicago-riqueña reside en la insistencia en un objetivo latino más amplio, incluso en el contexto de la fase nacionalista estadounidense-puertorriqueña, ampliamente minoritaria y más recientemente en el contexto feminista. La obra de los poetas de Nosotros, especialmente la de Hernández y Rivera, estableció las bases temáticas centrales de la escritura Chicago-riqueña de los años venideros. Estas temáticas se convertirían en debates políticos cruciales en las campañas que trajeron mayor representación puertorriqueña a niveles urbanos y estatales y en las polémicas que llevaron a muchos puertorriqueños primero a apoyar a Harold Washington y después a Richard Daley, además de la lucha local que llevó a Luis Gutiérrez al Congreso como uno de los representantes puertorriqueños claves en el país y que generó una resurrección cultural boricua como parte de la resistencia a la "gentrification" liderado por el activista comunitario José López. ${ }^{14}$

Los problemas de marginalización entre puertorriqueños/negros, puertorriqueños / mexicanos y las relaciones entre latinos en general, como también los problemas de feminismo que atraviesan todos los otros temas continuaron siendo importantes en Chicago y la emergencia de las narrativas pandilleras de Rey Sánchez sólo incrementó su visibilidad.

Para agregar una nota final a este ensayo, tras la publicación de los libros de Sánchez, Marisol Torres, estudiante y profesora a medio tiempo en la Escuela de

\footnotetext{
${ }^{14}$ Para tratamientos cruciales de los desarrollos comunitarios recientes, ver Ramos-Zayas; Pérez. La revista del Centro de Estudios Puertorriqueños publicó un número especial sobre Chicago, 13.2 (Fall 2001), con ensayos académicos y personales, fotografías y poesía de varios representantes de una nueva generación de estudiosos académicos y escritores de la comunidad Chicago-riqueña. También son importantes los dos libros publicados en el año 2002 por Nilda Flores y Tony Del Valle sobre la Escuela Secundaria Roberto Clemente -aunque aquí, para seguir en concordancia con Pérez, debemos hacer notar las transformaciones demográficas, lo que significa que la que fue fundada como la primera escuela secundaria puertorriqueña en la ciudad ahora tiene más estudiantes mexicanos que puertorriqueños.
} 
Estudios Fílmicos de Columbia en Chicago, terminó un largometraje, Chicago Boricua (estrenado en diciembre de 2005), que transcurre en la comunidad de Division Street y que se centra en tres historias: los esfuerzos de un ambicioso joven riqueño dispuesto a vender su comunidad y que para ello manipula estafas de bienes raíces para la compañía donde trabaja; el esfuerzo de una joven por parecer puertorriqueña para así poder competir por el título de reina en el desfile del día de Puerto Rico, y la tempestuosa relación amorosa de dos jóvenes riqueños en el área. Sin duda un buen primer esfuerzo, quizás demasiado enfocado en el sexo, la violencia y en el tema de alcanzar el éxito frente a la lealtad a la comunidad, esta película, que incluye a algunos reconocidos ciudadanos chicago-riqueños en papeles importantes, muestra que la comunidad y su crecimiento cultural siguen en la agenda, tanto como cuando el grupo Taller produjo la Antología Nosotros.

Por supuesto que las cosas no permanecerían igual para el resto del grupo original. Noboa se mudó a San Antonio a principio de los ochenta; Matías estuvo en la cárcel por un problema de drogas, pero salió en libertad hace varios años y en varias ocasiones ha amenazado con publicar su obra. Condes y otros se quedaron en Chicago pero dejaron de publicar. Como ya hemos señalado, Rivera falleció. Hernández se convirtió en parte del paisaje de Chicago con sus Streets Sounds [Sonidos callejeros], actuando durante todos estos años en escuelas y clubes nocturnos. Aún continúa actuando y recientemente recopiló algo de su mejor poesía, antigua y nueva, en un libro titulado The Urban Poems, publicado en el año 2004. Gamaliel Ramírez, uno de los fundadores del Taller y artista que apareció en la portada de Nosotros y en otro lugar de este ensayo, experimenta un nuevo momento de energía creativa que involucra no sólo nueva pintura sino también un desbordamiento de poesía que muy bien podría llevar a un libro. En la medida en que los chicago-riqueños se desplazan hacia el oeste de la zona de Humboldt y en la medida en que un sector más amplio de la comunidad progresa en sus esfuerzos por renovar y salvar las zonas centrales de lo que llegó a ser el Chicago puertorriqueño en la época del levantamiento de $1966,{ }^{15}$ algunos de los artistas y escritores que emergieron en las postrimerías del levantamiento continúan trabajando, incluso cuando surgen poetas y artistas más jóvenes que expresan las nuevas realidades de su tiempo.

Traducción: Francisco Ramírez Asesor de edición: Dra. Alicia Covarrubias

\footnotetext{
${ }^{15}$ [Nota del editor] El autor se refiere a los motines del verano de 1966 que sacudieron los barrios puertorriqueños de Chicago, que proveyeran el fermento político para las Fuerzas Armadas de Liberación Nacional (FALN) y cuyo legado todavía se refleja en el actual activismo urbano contra la "gentrification", así como en el apoyo a la candidatura de Luis Gutiérrez, congresista puertorriqueño por el distrito.
} 
BiBLIOGRAFÍA

Arocho, Eduardo. Poems Behind the Máscara. Chicago: Auto-publicado, 2002. Paseo boricua Renaissance. Chicago: Auto-publicado, 2003. The Fourth Tassel. Chicago: Auto-publicado, 2006.

Barillas, William. Midwest Latino Writers. Champaign: U of Illinois P (en prensa).

Barradas, Efraín. "Introducción”. Herejes y mitificadores: muestra de poesía puertorriqueña en los Estados Unidos. Efraín Barradas y Rafael Rodríguez, eds. Río Piedras: Huracán, 1981. 11-30.

Barry, John, ed. Voces en el viento: nuevas ficciones desde Chicago. Chicago: Editorial Esperante, 1999.

Cárdenas, Brenda y Johanny Vásquez, eds. Between the Heart and the Land/Entre el corazón y la tierra: Women Poets from the Midwest. Chicago: MARCH/ Abrazo Press, 2001.

Caruso, Jorge, Achy Obejas y Billy Zayas. Carnicería Rodríguez, Act. I. Ecos: A Latino Journal of People's Culture and Literature. Chicago: U of Illinois, 1983. 30-40.

Centro de Estudios Puertorriqueños. Número especial sobre Chicago. Bulletin, 13/2 (Fall 2001) <http://www.centropr.org/journal/jrnal24.html>

Cintrón, Ralph. Angel's Town: Chero Ways, Gang Life, and Rhetorics of the Everyday. Boston: Beacon Press, 1997.

Colón, Adolfo. Cantos de Seboruco. Chicago: Editorial El Coquí, 1989.

Del Valle, Tony. Written Literacy Features of Three Puerto Rican Family Networks in Chicago: An Ethnographic Study. Lewiston: E. Mellen Press, 2002.

Flores-González, Nilda. School Kids/Street Kids: Identity Development in Latino Students. New York: Teachers College Press, 2002.

Hernández, David. Despertando. Chicago: Auto-publicado, 1971. Satin-City Lullaby. Chicago: Auto-publicado, 1987.

Roof Top Piper. Chicago: Tía Chucha Press, 1991. and the Street Sounds. Liquid Thoughts. Vol. I; and Immigrants. Vol. II. 1. Chicago: Street Sounds Poetry/Music Workshop, Inc. Cassette tapes, 1988.

Levins Morales, Aurora y Rosario Morales. Getting Home Alive. Ithaca: Firebrand Books, 1986.

Lugo López, Lourdes. Poemas que me Desnudan y me Definan. Chicago: Editorial El Coquí, 1992.

Maciel, Olivia, ed. Shards of Light/Astillas de luz. Chicago: Tía Chucha Press, 1999.

Morton, Carlos. White Heroin Winter. El Paso: One-Eye Press, 1971. 
Ortega, Eliana. "Poetic Discourse of the Puerto Rican Women in the U.S.: New Voices of Anacaonian Liberation". Breaking Boundaries: Latina Writing and Critical Readings. Asunción Horno-Delgado, et al., ed. Amherst: U of Massachusetts P, 1989. 122-135.

Padilla, Félix M. Latino Ethnic Consciousness: The Case of Mexican Americans and Puerto Ricans in Chicago. Notre Dame: U of Notre Dame P, 1985.

Puerto Rican Chicago. Notre Dame: Notre Dame UP, 1987.

The Gang as an American Enterprise. New Brunswick: Rutgers UP, 1992.

y Lourdes Santiago. Outside the Wall: A Puerto Rican Woman's Struggle. New Brunswick: Rutgers UP, 1993.

Pérez, Gina M. The Near Northwest Side Story: Migration, Displacement, and Puerto Rican Families. Berkeley: U of California P, 2004.

Ramos-Zayas, Ana Y. National Performances: The Politics of Class, Race, and Space in Puerto Rican Chicago. Chicago: U of Chicago P, 2003.

Rivera, Edward. Family Installments: Memories of Growing Up Hispanic. Hammondsworth, Middlesex; New York: Penguin Books, 1983.

Rodríguez, Leonardo. They Have to be Puerto Ricans: The Label, the Lie, the Future. Chicago: Adams Press, 1988.

Sánchez, Reymundo. My Bloody Life: The Making of a Latin King. Chicago: Chicago Review Press, 2000.

Once a King, Always a King: The Unmaking of a Latin King. Chicago: Review Press, 2004.

Souchet, Clementina. Clementina: Historia sin fin. México: Auto-publicada, 1986.

Zimmerman, Marc. "A Meaty Slice of Life". Introducción a Carnicería Rodríguez, Act I. Ecos: A Latino Journal of People's Culture and Literature. Chicago: U of Illinois, 1983. 28-29.

"Transplanting Roots and Taking Off: Latino Poetry in Illinois". Studies in Illinois Poetry. John E. Hallwas, ed. Urbana: Stormline Press, 1989. 77-116.

"Defendiendo lo suyo en el frío: Puerto Rican Poets in Chicago". Latino Studies Journal I/3 (Sept. 1990): 39-58. 